Brit. J. industr. Med., 1961, 18, 133.

\title{
CHRONIC PULMONARY BERYLLIOSIS IN A FEMALE CHEMIST
}

\author{
BY \\ R. I. MCCALLUM, I. RANNIE, and C. VERITY \\ From the Nuffield Department of Industrial Health and the Department of Pathology, \\ King's College (University of Durham) and Royal Victoria Infirmary, Newcastle upon Tyne; \\ and the Chest Clinic, New Bridge Street, Newcastle upon Tyne
}

(RECEIVED FOR PUBLICATION FEBRUARY 6, 1960)

\begin{abstract}
A chronic progressive granulomatous disease of the lungs is described in a female chemist who worked for about two years with a beryllium compound in the manufacture of fluorescent lighting tubes. The level of beryllium in the laboratory atmosphere was found to be $2.7 \mu \mathrm{g}$. per cu.m. and in other parts of the factory up to $39.1 \mu \mathrm{g}$. per cu.m. were recorded. Symptoms began about two years after she left this work and she died three years later. A diagnosis of chronic pulmonary berylliosis was made, and confirmation was obtained by lung biopsy when early in the course of the disease a large cyst attached to the right middle lobe was removed by thoracotomy. Tests of lung function showed that there was a low arterial saturation at rest and a normal $\mathrm{PCO}_{2}$ in $\mathbf{s p i t e}$ of marked hyperventilation. Both elastance and resistance of the lungs were greater than normal and total work of breathing was six times the normal. Pregnancy was associated with relief of symptoms which persisted for some months after a normal birth. Death occurred about seven years after exposure to beryllium ceased. At necropsy beryllium was detected in the lungs chemically and demonstrated in histological sections by special stains. Microscopic examination of the lung showed conchoidal bodies and doubly refractile crystals and the pathogenesis of these lesions is discussed. It is suggested that there is a sensitivity reaction to beryllium, which is probably combined with protein to form an antigen, and that the breakdown of necrotic foci provokes a further reaction in the lung with the repeated appearance of fresh lesions.
\end{abstract}

Chronic beryllium granuloma of the lungs is a rare disease in the United Kingdom and only six case reports have been published (Agate, 1948; Sneddon, 1955, 1958; Rogers, 1957; Jordan and Darke, 1958; Wood, Ball, and Teare, 1958).

A further example from the United Kingdom of a patient with beryllium granuloma of the lungs is now presented, together with a necropsy report. A brief report of this case was given to the Pathological Society of Great Britain and Ireland (Rannie, 1956).

\section{Case Report}

In December 1952, a 27-year-old married female chemist attended hospital, complaining of recent breathlessness on exertion and a productive cough. A radiograph of the lungs suggested miliary tuberculosis (Fig. 2), although no tubercle bacilli were found in the sputum. At New Bridge Street Chest Clinic, Newcastle upon Tyne, it was discovered that between 1948 and 1950 she had handled material containing beryllium in a fluorescent lamp factory and that in July 1949 a chest radiograph had been taken which was normal (Fig. 1). Further investigations were carried out in Walker Gate Hospital (Table 1), where the urine was examined for beryllium without success. A cyst in the right lung which had been present when she was radiographed in December 1952 began to increase in size early in 1953 (Fig. 3), and breathlessness became so marked that it was removed.

This was done at the Newcastle Regional Chest Surgery Centre at Shotley Bridge by Mr. W. C. Barnsley, and the investigations made at this time are also shown in Table 1.

The cyst lay between the right middle and lower lobes and was attached to the lower aspect of the right middle lobe by a small pedicle of lung tissue (Fig. 4). The right lung was solid looking and difficult to inflate, its surface was studded with fine hard nodules, and it felt granular. There were some firm lymph nodes in the right hilum.

The histology of the cyst, some lung tissue attached to it, and some hilar lymph nodes, were reported on by Dr. J. D. McGregor of the Pathology Department, 


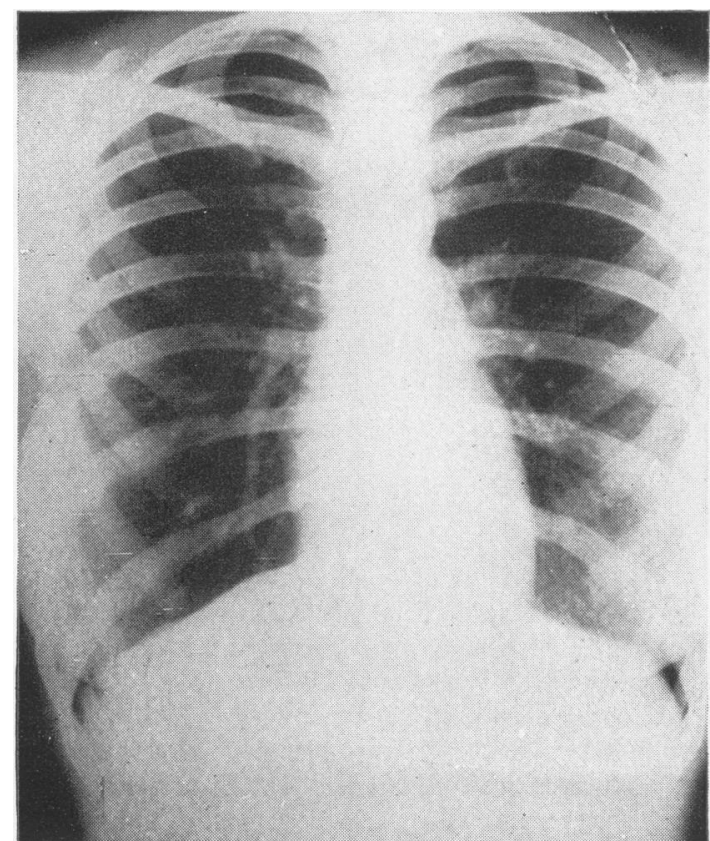

Fig. 1.-July 1949; normal radiograph of chest.

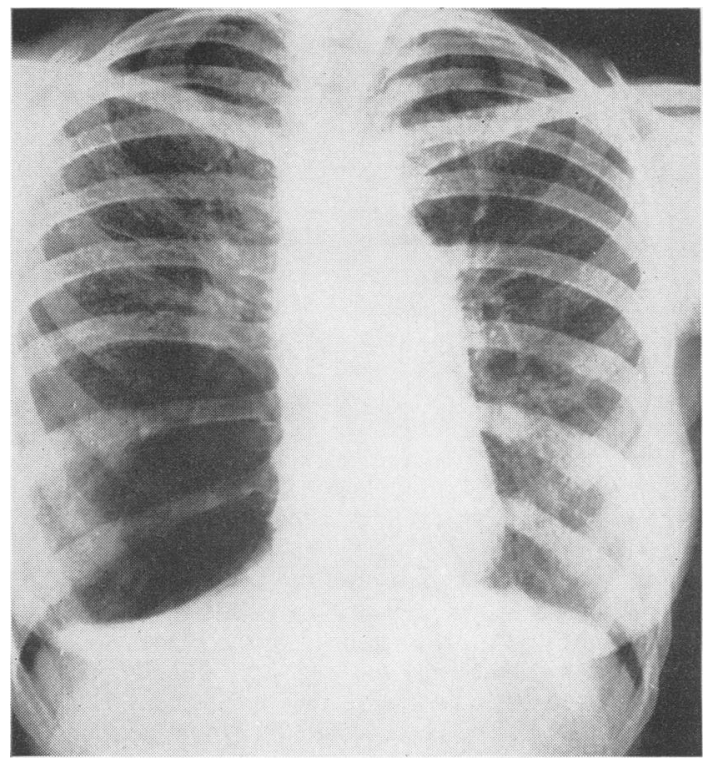

Fig. 3.-March 1953; cyst very much larger.



FIG. 2.-December 1952; fine granular opacities evenly distributed throughout both lungs (Category 3, mixed type); cyst in righ cardiophrenic angle and elevation of hilar structures.

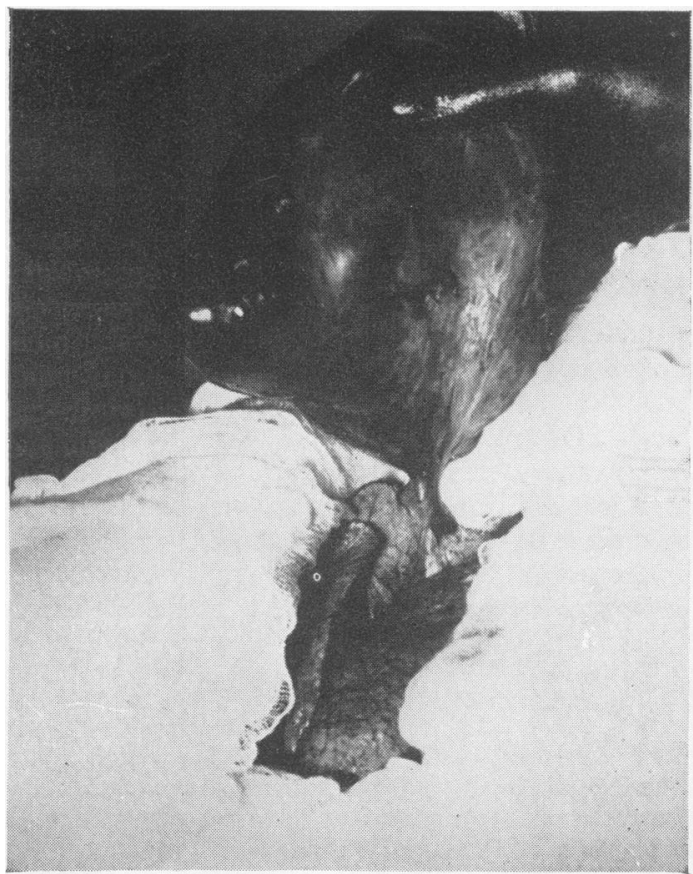

Fig. 4.-Right middle lobe at thoracotomy showing cyst attached to lower part of lobe (Department of Thoracic Surgery, Shotley Bridge General Hospital). 
TABLE 1

SUMMARY OF INVESTIGATIONS

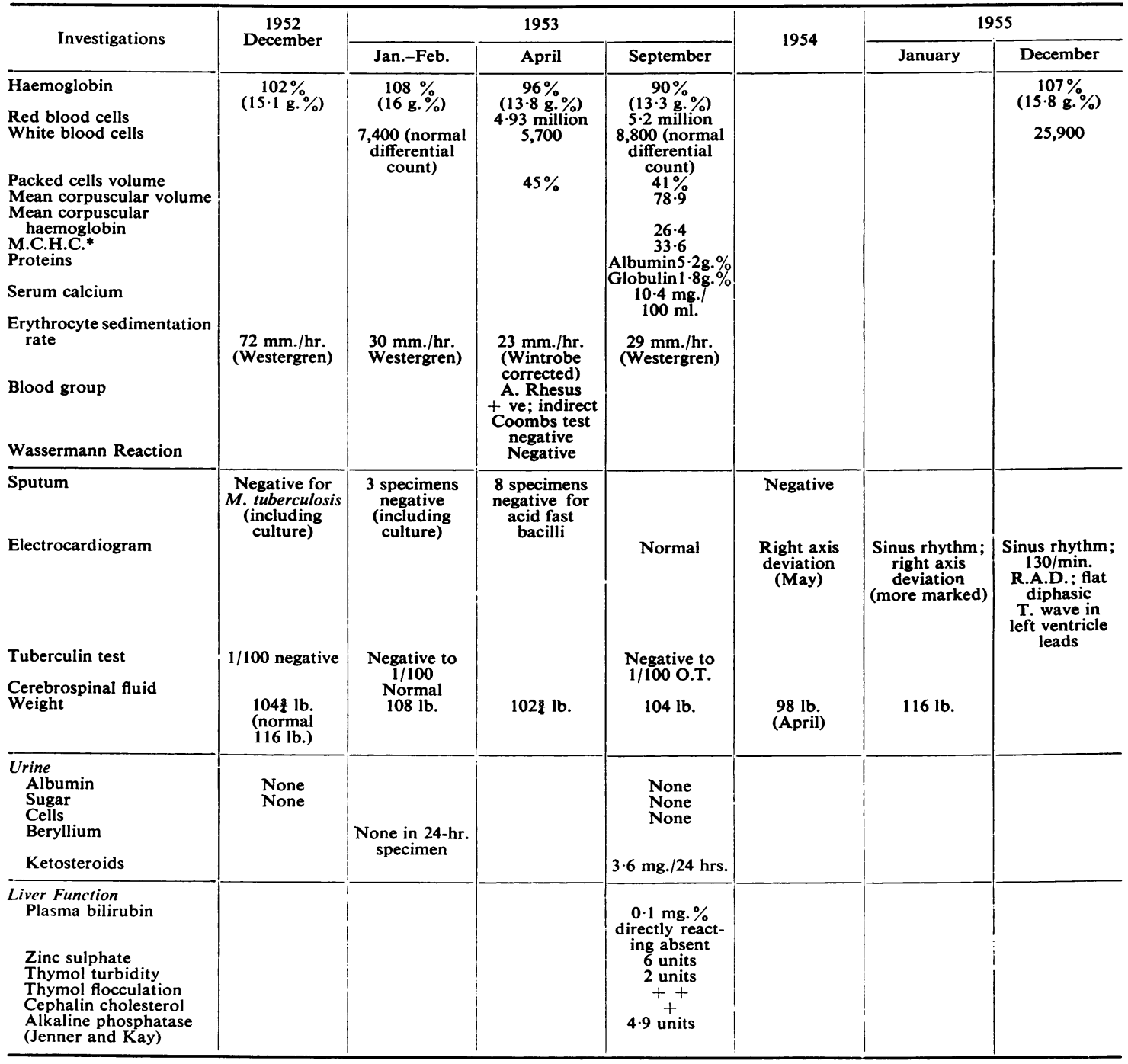

* Mean cell haemoglobin content.

University of Edinburgh, who found numerous discrete foci in the lung parenchyma consisting of multinucleated giant cells surrounded by lymphocytes. Many of the giant cells contained doubly refractile crystalline material. No purely fibrotic nodules or diffuse fibrosis was seen, and no caseation. He concluded that the pathology was consistent with berylliosis.

Occupational History.-At the age of 17 years the patient had six months training in chemistry and worked as a laboratory assistant in industry until 1948, when, at the age of 23 , she became works chemist for about two years to a firm manufacturing fluorescent lamps in County Durham. Zinc oxide $(47 \%)$, beryllium oxide $(3 \%)$, manganese carbonate $(3 \%)$, and powdered silica $(47 \%)$ were mixed dry, fused into a frit in an electric furnace and, after regrinding, mixed with acetone to form a paint. After leaving this job she did only clerical work and housework.

In October 1949 atmospheric samples were taken in the laboratory and other parts of the factory by the Department for Research in Industrial Medicine of the Medical Research Council. The beryllium was determined spectrographically after wet ashing the 
TABLE 2

PULMONARY FUNCTION TESTS

\begin{tabular}{|c|c|c|c|}
\hline Test & September 1953 & May 1954 & December 1954 \\
\hline $\begin{array}{l}\text { Maximum voluntary ventilation } \\
\text { Arterial blood } \mathrm{O}_{2} \text { saturation at rest } \\
\quad " \Rightarrow \quad " \quad \mathrm{O}_{2} \text { after five minute step test } \\
\text { Venous admixture (assuming mixed venous saturation) } \\
\text { Resting ventilation } \\
\text { Ventilatory equivalent for oxygen (at rest) }\end{array}$ & $\begin{array}{l}441 . / \mathrm{min} . \\
91 \% \\
73 \% \\
21 \% \mathrm{~mm} . \mathrm{Hg} \\
14 \% \\
7.51 . / \mathrm{min} . \\
-\end{array}$ & $\begin{array}{l}541 . / \mathrm{min} . \\
= \\
\bar{Z} \\
\overline{33}\end{array}$ & $\begin{array}{l}401 . / \mathrm{min} . \\
91 \% \\
\overline{41} \mathrm{~mm} . \mathrm{Hg} \\
14 \% \\
\frac{35}{35}\end{array}$ \\
\hline $\begin{array}{l}\text { Mechanical properties of lungs } \\
\text { Functional elastance } \\
\text { Mean resistance } \\
\text { Work of inspiration } \\
\text { Total non-elastic work of inspiration and expiration } \\
\text { Active expiration }\end{array}$ & $\begin{array}{l}- \\
- \\
-\end{array}$ & $\begin{array}{l}- \\
- \\
-\end{array}$ & $\begin{array}{l}39 \mathrm{~cm} . \mathrm{H}_{2} \mathrm{O} / \text { litre } \\
(\text { compliance }=0.0256) \\
15 \mathrm{~cm} . \mathrm{H}_{2} \mathrm{O} / \text { litre } / \mathrm{sec} . \\
0.23 \mathrm{~kg} \cdot \mathrm{m} . / \text { litre* } \\
\text { (elastic work }=83 \% \text { of total) } \\
0.127 \mathrm{~kg} \cdot \mathrm{m} . / \text { litre* } \\
0.012 \mathrm{~kg} \cdot \mathrm{m} \text {./litre* }\end{array}$ \\
\hline
\end{tabular}

* These figures multiplied by 8 give the work of breathing in kilogram metres per minute.

samples. In the laboratory itself an air sample collected over a period of 75 minutes on one day contained beryllium $2.7 \mu \mathrm{g}$. per cu.m. The level in the pulverizer room was $29.6 \mu \mathrm{g}$. per cu.m., while in the furnace room $39 \cdot 1 \mu \mathrm{g}$. per cu.m. were recorded.

Radiograph of Lungs.-A radiograph of the lungs taken in August 1953 showed bilateral evenly distributed fine mottling, without tendency to coalesce and with no cysts or areas of emphysema. It was similar in extent to the standard film of Category 3 mixed type of pneumoconiosis (Pneumoconiosis Research Unit, Cardiff). Absence of part of the right sixth rib, filling in of the costophrenic angle, and a small right apical pneumothorax remained after the thoracotomy. There was also a prominent left border to the heart and some elevation of the hila, especially on the right side. Investigations as an in-patient at this time (September 1953) are shown in Table 1.

Tests of pulmonary function were carried out by Dr. G. L. Leathart, as shown in Table 2. The low arterial saturation at rest is consistent with the diagnosis of a destructive lung lesion such as chronic beryllium granuloma. The earliest physiological abnormality in chronic berylliosis is an impediment to the transfer of oxygen across the gas-blood interface of the lung, probably at the alveolar membrane (Wright, 1950), and the fall in saturation during exercise in this patient suggested that this was the case. Estimation of diffusing capacity would therefore have been of value, but could not be made at this time.

Progress.-Between December 1952 and April 1954 the patient lost nearly $7 \mathrm{lb}$. in weight, but felt fairly well. The chest radiograph showed, in addition to the earlier changes, broadening of the mediastinum and cyst formation in the right upper zone.

In October 1954 she became pregnant, her breathlessness was much improved, and she lost a morning wheeze which had previously troubled her. There was now early finger clubbing and râles were present diffusely in both lungs. In the electrocardiogram right axis deviation, which first appeared in May 1954, was more obvious.

Further physiological investigations of lung function were made (see Table 2). Despite considerable hyperventilation $\left(\mathrm{Vo}_{2}=33-35\right)$ the arterial $\mathbf{P C O}_{2}$ was normal, suggesting defective distribution of inspired air to those alveoli which were being perfused. Resistance was calculated from records of intraoesophageal pressure and respiratory excursion; elastance is derived from these records, and from a pressure-volume diagram drawn from an oscilloscope. The elastance was measured during normal respiration and is a dynamic or functional elastance rather than a static one. The work done was calculated from the area enclosed by the pressurevolume diagram. In all cases the figure given is the mean of a number of different breaths. Both the elastance and the resistance are greater than normal, and this is reflected in the total work of breathing which is about six times as great as normal. The increased elastance might well be due to fibrosis of the lungs and is much greater than can be accounted for by the lobectomy. The increased resistance suggests obstruction or distortion of the airways, and the blood chemistry supports this.

In January 1955 she had a left spontaneous pneumothorax (Fig. 5). The radiological lung changes were now coarser and the translucent area in the right upper zone was larger.

In May 1955 she had an uneventful delivery of a normal child under the care of the Department of Obstetrics and Gynaecology of Newcastle General Hospital.

She remained fairly well, apart from breathlessness on exertion, until in December 1955, she went into acute right heart failure during a spell of foggy weather and died two days after admission to hospital.

Pathology.-At necropsy there were greatly enlarged mediastinal lymph nodes which showed a reddish oedematous cut surface with here and there some grey speckling. A small calcified focus about $0.2 \mathrm{~cm}$. in diameter was present in the inferior group, but there was no other evidence of tuberculosis. The heart weighed $250 \mathrm{~g}$. and showed dilatation of the right side with hypertrophy of both auricular and ventricular muscles. The left side was normal. 
The lungs together weighed $1,600 \mathrm{~g}$. The parenchyma of the right upper lobe was almost entirely replaced by a large smooth-walled cavity about 5 to $6 \mathrm{~cm}$. in diameter, traversed by fibrous cords and communicating with a bronchus to the upper lobe. Smaller cavities, up to $2 \mathrm{~cm}$. in diameter, were also present throughout the upper lobe. The cavities were mainly anterior, while posteriorly the lung tissue was oedematous and contained multiple small firm greyish spots less than $1 \mathrm{~mm}$. in diameter, and similar to miliary tubercles. They appeared to be more numerous in the middle lobe and in the upper portion of the lower lobe than in the upper lobe. The left lung was distended with formalin for section later (Fig. 6).

Histology of Lungs.- There are three distinct types of lesion: first, very small collections of epithelioid cells, with or without central necrosis, and usually in relation to a conchoidal body (Fig. 7). These lesions are mainly in the lower lobes in relation to the respiratory bronchioles and are similar in position to the early lesions of tuberculous bronchopneumonia, to which they bear a strong morphological resemblance. One or more Langhans type giant cells may be present, but the giant cell reaction is mostly of the foreign body type, and they contain foreign material which is sometimes doubly refractile (Fig. 8).

The second type of lesion is slightly larger and visible to the naked eye as a pin-head grey nodule. It consists of a central zone of hyaline eosinophilic material without recognizable nuclei, and there are usually several giant cells containing conchoidal bodies at the periphery

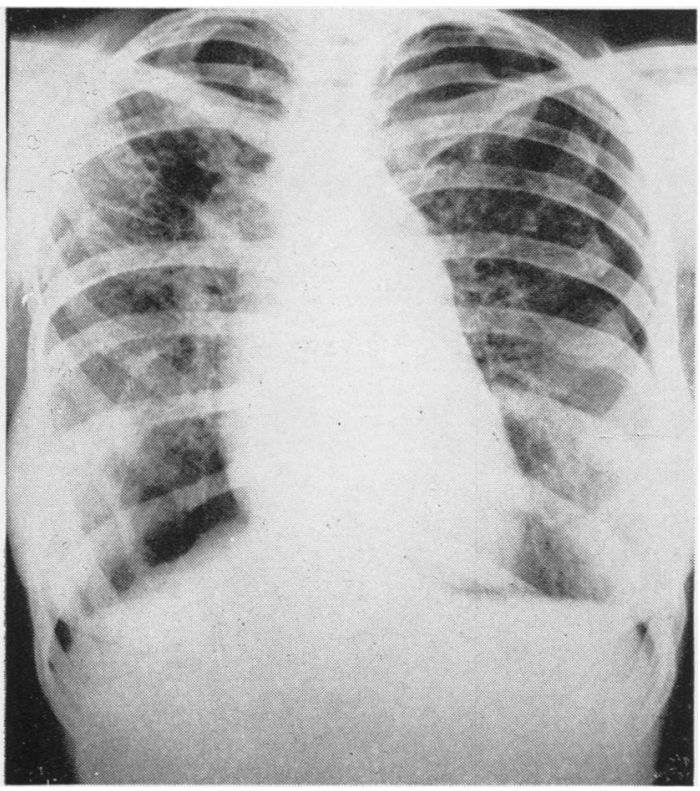

Fig. 5.-January 1955; left pneumothorax and enlarged heart with prominent pulmonary arteries. The lung shadows are now coarser and there is a translucent area in the right upper lobe.

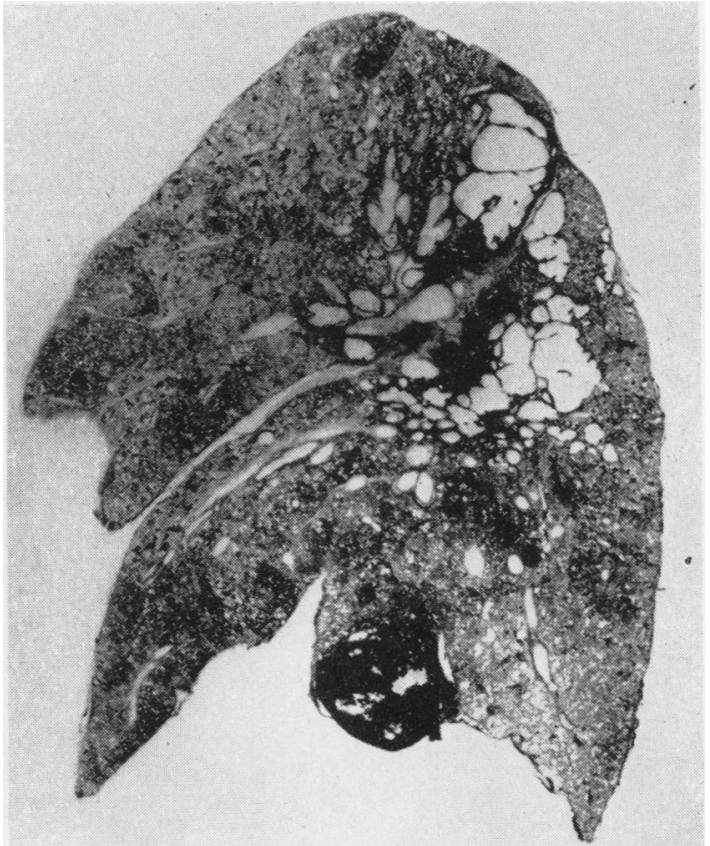

Fig. 6.-Sagittal section of left lung showing large central cysts, some of which are dilated bronchi. The small lung leşions are not visible. There is a recent infarct at the lung base.

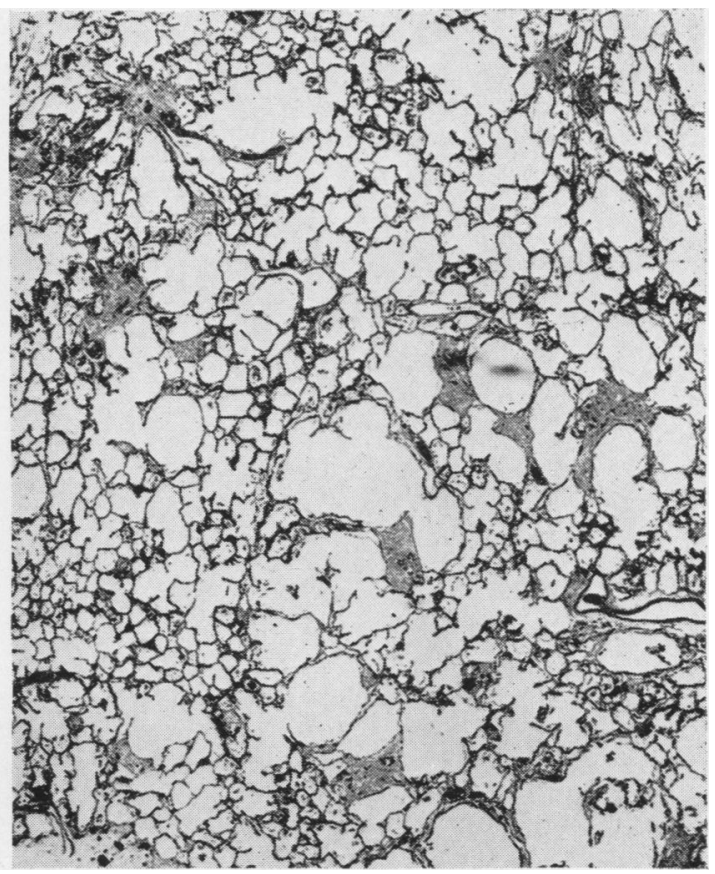

FIG. 7.-Lung showing early lesions with surrounding emphysema (H. and E. $\times 23$.) 


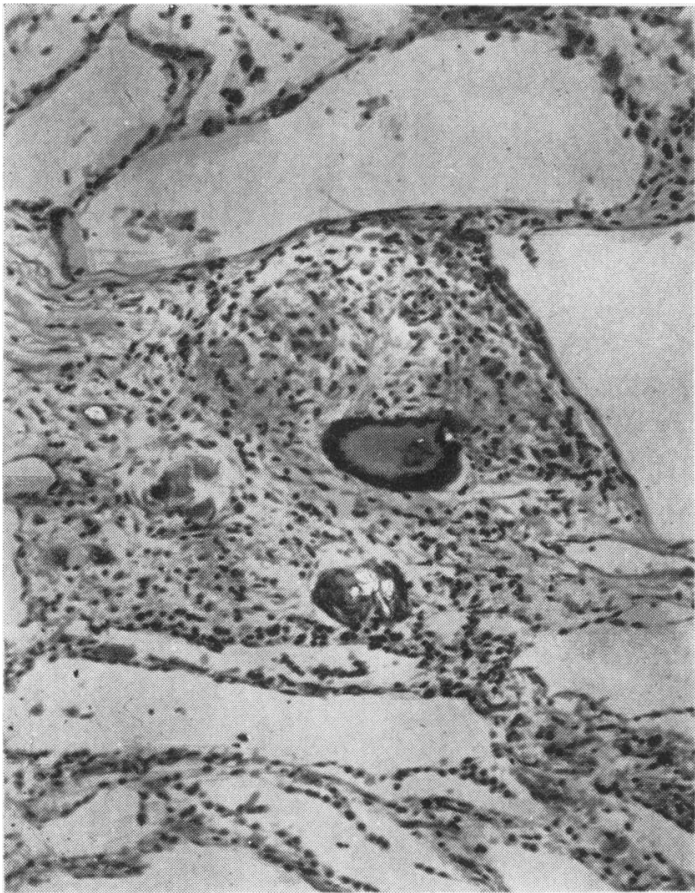

Fig. 8.-Lung; partially crossed polarized light with doubly refractile material in a multinucleated giant cell, surrounded by epithelioid cells. (H. and E. $\times 100$.)

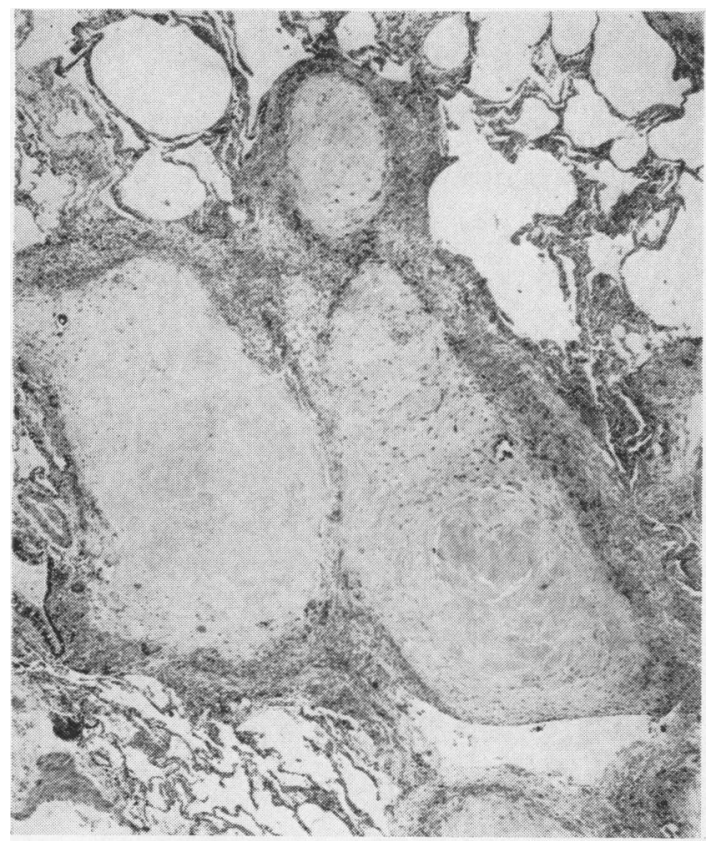

Fig. 9.-Lung; later lesion showing central necrosis, and resembling a caseous tubercle. (H. and E. $\times 36$.)

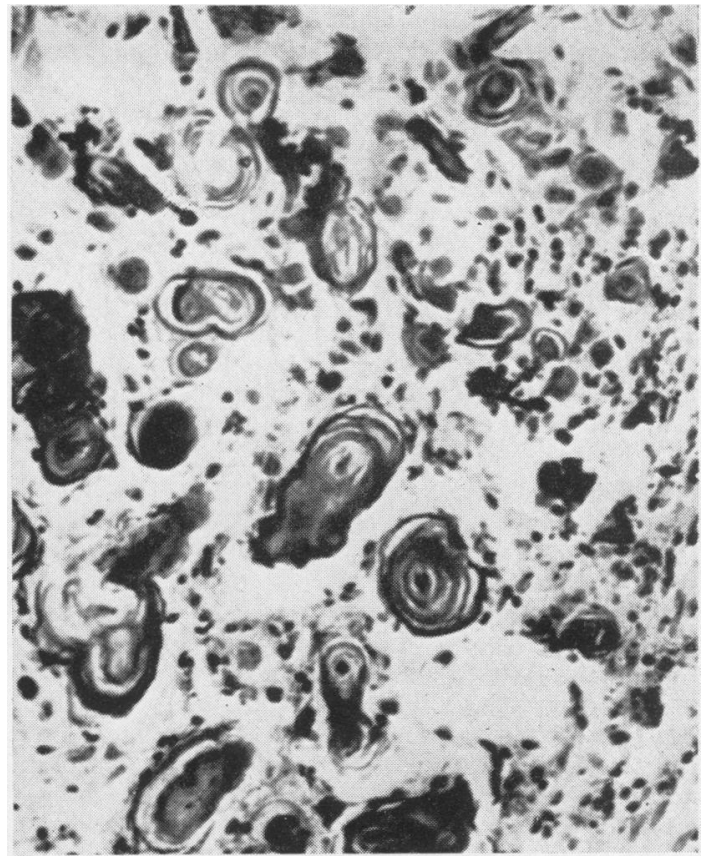

FIG. 10.-Lung; collection of conchoidal bodies in upper lobe cavity. (H. and E. $\times 270$.)

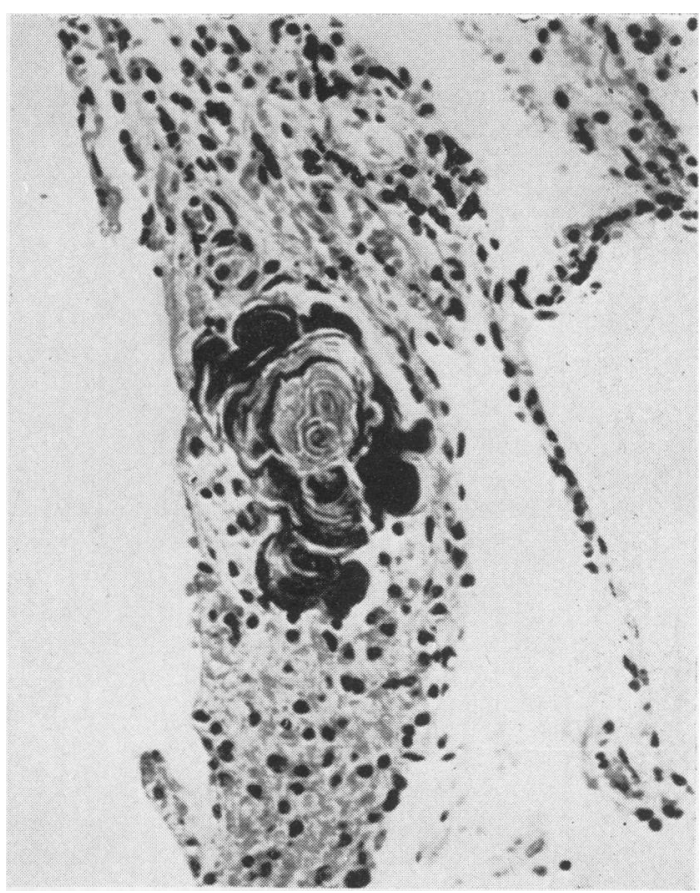

Fig. 11.-Lung; high power view of conchoidal body in an early granuloma. (H. and E. $\times$ 375.) 
(Fig. 9). The conchoidal bodies show concentric basophilic lamellae surrounding crystalline doubly refractile material (Figs. 10 and 11). This type of lesion is usually surrounded by fibrous tissue, and it greatly resembles inactive or slowly progressive fibrocaseous tuberculosis, or silicosis. The lesion appears to enlarge slowly and may coalesce with neighbouring lesions. It seems probable that they eventually break down and discharge their contents into the bronchi to form the third type of lesion which is a smooth-walled space resembling a chronic tuberculous cavity traversed by cords formed by vessels and bronchi. The walls of these cavities are fibrous and without obvious epithelial lining, and many of them contain large numbers of the conchoidal bodies.

Transitional stages can be traced between the early tubercle-like granulomas and the later pin-head type. The mediastinal lymph nodes contain hard areas of hyaline change similar to that found in silicosis, and there are conchoidal bodies and giant cells as in the lungs.

No tubercle bacilli were found on direct examination or on culture of the tissues. By specific staining methods (Denz, 1949; Pearse, 1957) beryllium was demonstrated in conchoidal bodies in both the lungs and in regional lymph nodes. Dr. A. S. Curry of the North East Forensic Science Laboratory, Harrogate, using arc emission spectrography with a limit of detection of $0.1 \mu \mathrm{g}$., reported beryllium in the lung on chemical examination in a concentration of $20 \mu \mathrm{g}$. per $100 \mathrm{~g}$. formaldehyde treated wet tissue. A mediastinal lymph gland also contained beryllium in a concentration of $10 \mu$ g. per $100 \mathrm{~g}$. tissue.

Some tissues were also analysed by Dr. J. Steel of the Department of Industrial Health, using a method described by Aldridge and Liddell (1948) which is specific for beryllium in biological material except bone, and suitable for quantities greater than $1 \mu \mathrm{g}$. The results were as follows:

Lymph node

Lung

Mediastinal gland

$100 \mu \mathrm{g} . / 100 \mathrm{~g}$. wet tissue

$40 \mu \mathrm{g} . / 100 \mathrm{~g}$. wet tissue

$6 \mu \mathrm{g} . / 100 \mathrm{~g}$. wet tissue.

Specimens of tissue from pectoral muscle, liver, kidney, and spleen did not contain any beryllium.

\section{Discussion}

In Europe before and during the Second World War acute illness from the use of beryllium in industry was observed and described, together with necropsy findings. Chronic beryllium pneumonitis of delayed onset was first described in America by Hardy and Tabershaw in 1946. In the United States beryllium was used very little until 1938, after which there was rapid expansion of the fluorescent lamp industry, when large numbers of workers handled beryllium phosphors in various proportions.

Manufacture of fluorescent lamps in Great Britain did not begin on a large scale until after 1945 , and a smaller amount of beryllium (often only $5 \%$ ) was used in the phosphors than in the United
States (Williams, 1956). In the United Kingdom five out of six workers affected by beryllium pneumonitis were chemists engaged in the development of beryllium lamp powders (McLaughlin, 1955), and of the six reported cases of chronic lung disease four were exposed to the dust of these powders, the remaining two being in contact with $2 \%$ beryllium-copper alloy. The particularly hazardous nature of lamp manufacture arose from the mixing and grinding of powder and from cleaning off phosphor deposited on the inside of the glass tubes, all of which produced dust. Ignorance of the deadly nature of the powder which existed in the industry until about 1948 resulted in lack of adequate precautions, even although the use of powdered silica in high proportion by itself suggests the need for stringent precautions.

In our patient the diagnosis of berylliosis was made during life on the combination of typical radiological changes, an occupational history of exposure to a beryllium compound, a lung biopsy showing granulomatous changes, and the characteristic clinical course of the disease. At necropsy confirmation was obtained from the full lung histology and chemical analysis of tissues for beryllium. We have also demonstrated beryllium in lung sections using the dye solochrome azurine which was shown by Pearse (1957) to form an almost black complex with beryllium in neutral or alkaline solution.

The insidious onset with lassitude, loss of weight, breathlessness, and the discovery of bilateral disseminated infiltration in the lungs which was at first confused with miliary tuberculosis and the progressive fibrosis, cyst formation, spontaneous pneumothorax, cor pulmonale, and death from heart failure, are typical of reported cases (Slavin, 1952; Hardy, 1955; Williams, 1956). A diagnostic patch test was not used in view of the reported reaction in a patient to such a test (Sneddon, 1955), when for several days afterwards dyspnoea appeared to get worse and moist râles appeared in the lungs for the first time.

Our view that the histological changes in the lungs and lymph nodes in our patient are characteristic of chronic beryllium granuloma was confirmed by Jones Williams (1958) who included sections of her lung in a review of material from 52 patients with the disease; the great majority were from the United States.

In the present case a prominent feature, of which there are other examples in the literature, was the tendency to cyst formation (Fig. 6). The cavities persisted and enlarged, presumably because of destruction of lung tissue by the granulomatous process, and they interfered with ventilatory function 
by increasing the dead space and compressing adjacent lung.

Pregnancy in patients with berylliosis has been recorded, but there are conflicting opinions about its effects on the course of the disease. The effect of pregnancy in our patient appeared to be beneficial, and her symptoms improved so much that treatment with corticotrophin was withheld. After delivery the feeling of well-being was maintained, although she continued to be breathless on exertion.

Enlargement of the adrenal cortex occurs in pregnancy, and Venning (1946) has shown that there is a rise in urinary corticoids to relatively high values. After parturition excretion returns to normal levels again. The subjective improvement during pregnancy which our patient noticed could have been due to the effect of relatively high corticoid production, but the improvement was maintained for about six months after the child was born, during which corticoid output was presumably normal.

In other case reports from the United Kingdom beryllium was not found in the patients' tissues. Wood et al. (1958) detected none on chemical analysis of lung and Sneddon (1955) found none in skin. In our patient beryllium was demonstrated in lung sections and its concentration was estimated in portions of lung and lymph gland. In 1949 Denz, using naphthochrome green B, showed that soluble beryllium salts, which readily combine with protein and cause local necrosis, were easily identified by staining. On the other hand, the refractory oxide of beryllium and the silicate which are insoluble in water were not readily stained and did not produce necrosis. Deposits as small as $2 \mu \mathrm{g}$. are detectable by this method. In the present case the stain gave positive results with much of the foreign material in the lung. This suggests that insoluble beryllium in the lung may eventually become soluble and combine with protein, and exert a toxic action on the tissue.

Two lesions characteristic of the beryllium lesion are present in material from our patient; inclusion bodies and a series of concentric lines round them (Figs. 10 and 11). Pearse (1957) shows a section of lymph node from our patient stained with solochrome azurine in which there is a crystalline doubly refractile deposit surrounded by a black zone where a soluble beryllium salt is combined with protein. The concentric lines round the deposit are similar to those described by Wood et al. (1958) in a section of lung from their patient. In their case there were numerous inclusion bodies both in giant cells and extracellularly, consisting of long refractile needles and conchoidal bodies.
The latter had an irregularly shaped central part which was either a deeply stained amorphous mass or colourless plates not refractile to polaroids, with a series of concentric lines, the outer being heavy and the inner ones thinner. These bodies contained calcium and iron. In spite of the long clinical history fibrosis was not a feature of their case.

In our patient the nature and origin of the doubly refractile crystals is obscure. Pearse (1957) appears to assume that the crystalline doubly refractile body shown in the histological section of a lymph node from our patient is beryllium, but produces no evidence in support of this. After incineration the crystals disappear on treatment with acid and are therefore not silica. Whatever their nature they appear to be a product rather than the cause of the reaction, for they are too large to reach the alveoli in the inspired air and appear to be much too large to be carried to the mediastinal glands by lymphatics.

Our patient was exposed to several different substances in the course of her work. During 1949 she handled a mixture containing $3 \%$ beryllium oxide in a dry state and $47 \%$ powdered silica, at first without any form of protection, although gauze masks were supplied later. She was also exposed to the same materials after they had been fused and ground, and there was therefore not only the possibility of the inhalation of silica and beryllium, but also of the crystalline form of silica, cristobalite, which is seldom found naturally but may be produced by heating silica to high temperatures. It can produce granulomatous changes in the lungs (Vigliani and Mottura, 1948), and is a more fibrogenic substance than quartz though less so than tridymite, another form of silica (Zaidi, King, Harrison, and Nagelschmidt, 1956). Both quartz and cristobalite were detected by $x$-ray diffraction in lung tissues from our patient. In an attempt to identify the individual crystalline particles seen in the lung sections, their refractive indices were measured by Dr. M. H. Battey of the Geology Department, King's College, University of Durham. Extreme values of 1.488 and 1.611 were found, a large proportion of grains examined having an index near $1 \cdot 488$. The grains dissolved in dilute $(1: 9)$ hydrochloric acid without effervescence, and we confirmed this. The findings suggested that several different substances were present and that the predominant crystals were not cristobalite or any form of silica, although these might also have been present in the lung; nor were they manganese carbonate or zinc oxide, both of which she handled. In diatomaceous earth pneumoconiosis, which is probably due to inhalation of cristobalite, the lung lesion differs from that found in berylliosis. It is a diffuse granulomatous change 
affecting primarily the alveolar walls but extending into alveoli, and later becoming fibrotic. The giant cells are scanty and there are no tubercle-like aggregations (Vigliani and Mottura, 1948).

Jones Williams (1958) points out that the doubly refractile crystals which are present in $80 \%$ of conchoidal bodies are not diagnostic of beryllium disease, as they are identical with those found in sarcoidosis, and that conchoidal bodies are also found in tuberculosis, sarcoidosis and silicosis. He believes (1959, personal communication) that the crystals are probably calcite, that the conchoidal bodies are composed of calcium-impregnated protein, and that they are secondary to the crystal formation. Calcite has refractive indices of 1.486 and 1.658 which is consistent with our findings, except that a majority of crystals with the higher index might be expected. Furthermore, we did not observe effervescence with hydrochloric acid which should occur if the crystals were calcium carbonate. In caseation there is deposition of calcium salt usually combined with phosphates. In our patient, although phosphate was probably present as shown by testing with ammonium molybdate, carbonate might well be the main constituent. Why crystals are formed in this way still remains to be explained.

The histological changes in the lungs of this patient strongly suggest a continuous process with lesions of different ages, beginning as microscopic granulomas containing giant cells and foreign material, and progressing to macroscopic nodules with central necrosis and fibrosis. Finally, there is cyst formation by discharge of material containing beryllium-protein complex which can spread throughout already sensitized lung by the bronchi and lymphatics to give new lesions. This mechanism will explain the formation of fresh lesions even after a long period since the initial exposure to beryllium. It is known that beryllium may be retained in the body tissues for up to 10 years (Klemperer, Martin, and Van Riper, 1951), particularly in the lungs.

The analogy with tuberculosis, and perhaps with sarcoidosis, is strong. Assuming that beryllium combines with tissues or plasma protein to form an antigen and that isoimmunity develops, it is possible that if the release of beryllium-protein compound in a soluble or easily available form occurs slowly but continuously, the conchoidal bodies result from a "Liesegang" phenomenon (Van Oss and Hirsch-Ayalon, 1959), in which concentric lines of protein precipitate attract a deposit of calcium and iron. The Liesegang phenomenon occurs in antibodyantigen systems, as seen in gels (Feinberg, 1957), and was originally described in connexion with inorganic salts in porous media or gels (Liesegang,
1896; Van Oss and Hirsch-Ayalon, 1959). This suggests that conchoidal bodies may be formed in very slowly progressive granulomas, and it is interesting that they occur in silicotic lesions but have not been reported in rheumatic nodules. The silicotic nodule may also have an immunological origin (Vigliani, 1958).

The slow liberation of beryllium may also lead to tissue destruction through direct necrosis (Aldridge, Barnes, and Denz, 1949) wherever beryllium is deposited, whether in lung or lymph nodes.

The tendency of beryllium salts to cause dermatitis and the response of patients with berylliosis to patch tests with material containing beryllium salts suggest a sensitivity reaction in certain individuals. The rarity of lung disease amongst those exposed to beryllium (DeNardi, Van Ordstrand, Curtis, and Zielinski, 1953), and the minute quantities which must in some instances have led to the chronic lung disease, also support this.

Sterner and Eisenbud (1951), in a detailed discussion of the possible mode of action of beryllium in the human body, consider that granuloma is one of the histopathological lesions of allergy, and that the essential mechanism in beryllium granuloma is a modified immunological reaction.

Recently, sensitivity has occurred to very small amounts of another rare metal, zirconium, used as sodium zirconium lactate in stick deodorants, with the formation of axillary granulomas composed of epithelioid cells and giant cells surrounded by lymphocytes (Rubin, Slepyan, Weber, and Neuhauser, 1956; Shelley and Hurley, 1958). Sensitivity to beryllium appears to be of quite a different order compared to that of zirconium sensitivity which is not associated with lung lesions, and it presents a very difficult problem in prevention. Because such minute quantities of beryllium can cause profound results, not only must the atmospheric concentration be kept rigidly under control, but individuals known by skin tests to be sensitive to it should not be allowed in the vicinity of processes in which it is being used. Williams (1956) quotes a provisional figure of $2.0 \mu \mathrm{g}$. per cu.m. air as the "daily weighted average exposure" below which atmospheric levels should be kept.

In the laboratory in which our patient worked a single estimation of beryllium in air was $2.7 \mu \mathrm{g}$. per/cu.m., but in other parts of the factory to which she had access the levels recorded were 10 or 20 times as much and it is likely that her exposure was heavy.

No other case of berylliosis from this factory is 
known to us, although a number of men and women were employed on the same process during the relatively short period during which beryllium was in use. The company went into liquidation in March 1950, but in 195322 of the former employees were traced and had chest radiographs. Again in 195611 former employees were radiographed, two of them for the first time. No gross abnormality was seen in any of the films, but in one man of 59 years who was once a coal-miner for 10 years there were dust opacities of Category 1 or less which had not progressed between 1953 and 1956.

We wish to thank the following for their much valued help in preparing this report: Mr. W. C. Barnsley of Shotley Bridge Hospital for details of the thoracotomy, and Fig. 4; Dr. J. D. McGregor of Edinburgh for his report on the lung biopsy; Mr. G. C. Liggins of the Department of Obstetrics and Gynaecology, Newcastle General Hospital, for a report on her delivery; Dr. A. S. Curry of the North East Forensic Science Laboratory, Harrogate, for his report on tissue beryllium; Dr. M. H. Battey of the Department of Geology, King's College, for his report on the foreign bodies in the lung; Dr. Buchanan, Medical Inspector of Factories, for information on working conditions; Dr. G. L. Leathart and Dr. J. Steel of the Department of Industrial Health for tests of lung function and chemical analyses; Dr. Donald Hunter of the Medical Research Council's Department for Research in Industrial Medicine for permission to quote figures for beryllium in air. Dr. E. Brauer of Spennymoor was very helpful in tracing former employees of the factory. Mr. A. E. Young prepared the large sections and gave invaluable help with the photography.

\section{REFERENCES}

Agate, J. N. (1948). Lancet, 2, 530.

Aldridge, W. N., and Liddell, H. F. (1948). Analyst, 73, 607. -, Barnes, J.' M., and Denz, F. A. (1949). Brit. J. exp. Path., 30, 375 .

DeNardi, J. M., Van Ordstrand, H. S., Curtis, G. H., and Zielinski, J. (1953). Arch. industr. Hyg., 8, 1 .

Denz, F. A. (1949). Quart. J. micr. Sci., 90, 317

Feinberg, J. G. (1957). Int. Arch. Allergy, 11, 129.

Hardy, H. L. (1955). A.M.A. Arch. industr. Hlth., 11, 273.

Hardy, H. T. (1955). A.M.A. Arch. industr. Hith., 11, 273.

$\overline{\text { Jones Williams, W. (1958). (Brit. J. industr. Med., 15, } 84 .}$

Jones Willams, W. (1958). Brit. J. industr. Med., 15, 84.

Klemperer, F. W., Martin, A. P., and Van Riper, J. (1951). Arch. industr. Hyg., 4, 251.

Liesegang, R. E. (1896). Naturw. Wschr., 11, 353. Quoted by Van Oss. C. J., and Hirsch-Ayalon, P. (1959). Science,

McLaughlin, A. I. G. (1955). A.M.A. Arch. industr. Hlth, 12, 83.

Pearse, A. G. E. (1957). Acta histochem. (Jena.), 4, 95.

Rannie, I. (1956). Paper read to Path. Soc. of Great Britain and Ireland.

Rogers, W. N. (1957). Lancet, 2, 267.

Rubin, L., Slepyan, A. H., Weber, L. F., and Neuhauser, I. (1956). J. Amer. med. Ass., 162, 953

Shelley, W. B., and Hurley, H. J. (1958). Brit. J. Derm., 70, 75.

Slavin, P. (1952) Amer. Rev. Tuberc., 65, 142.

Sneddon, I. B. (1955). Brit. med. J., 1, 1448.

(1958). Postgrad. med. J., 34, 262.

Sterner, J. H., and Eisenbud, M.. (1951). Arch. industr. Hyg., 4, 123. Van Oss, C. J., and Hirsch-Ayalon, P. (1959). Science, 129, 1365.

Venning, E. M. (1946). Endocrinology, 39, 203.

Vigliani, E. C. (1958). Med. d. Lavoro, 49, 1 .

Vigliani, E. C. (1958). Med. (1948). Bavit. J. industr. Med., 5, 148

Williams, K. (1956). The Natural History of Beryllium Poisoning. A.E.R.E., Harwell.

Wood, C. H., Ball, K. P., and Teare, N. D. (1958). Brit. J. industr. Med., 15, 209.

Wright, G. W. (1950). In Pneumoconiosis, ed. A. J. Vorwald, p. 173. (Leroy U. Gardner Memorial volume). Hoeber, New York.

Zaidi, S. H., King, E. J., Harrison, C. V., and Nagelschmidt, G. (1956). A.M.A. Arch. industr. Hith, 13, 112. 